\title{
MEDICAL VIROLOGY OF SMALL ROUND GASTROENTERITIS VIRUSES
}

\author{
Neil R. Blacklow \\ University of Massachusetts Medical School \\ Division of Infectious Diseases, \\ Department of Medicine \\ Worcester, Massachusetts, 01655, USA
}

\section{SPECTRUM OF VIRAL GASTROENTERITIS AGENTS}

Despite the medical importance of viral diarrheas, the responsible etiologic agents were totally unknown until the discovery of Norwalk virus in 1972 (Kapikian et al. 1972). The main reason for this delay in their recognition was the inability to cultivate in cell culture etiologic agents from stool specimens. This was in marked contrast to the success in cultivating the many viruses causing respiratory tract disease, measles, mumps and other common viral syndromes. It was only when electron microscopic (EM) and antigen detection techniques were applied to the study of stool specimens that viral gastroenteritis agents were discovered and their medical importance subsequently ascertained.

Since 1972, a number of etiologic agents of human viral gastroenteritis have been discovered (Cukor and Blacklow, 1984). They are summarized in Table 1. Rotavirus is the best known and studied pathogen, and it also is the agent most responsible for medically important diarrheal disease, being the principal cause of gastroenteritis of infants and young children worldwide. A few strains of morphologically indistinguishable rotaviruses lack a common viral group antigen and are therefore called non-group A rotaviruses. To date, these have been associated with disease only in China. Another category of pathogens is the enteric adenoviruses, which are the only adenovirus strains (serotypes 40 and 41) that are clearly associated with diarrheal disease. They appear to be a distant second in importance to rotaviruses as a cause of endemic diar-rhea of infants and young children in temperate climates. Enteric coronaviruses have been described in stool samples from both ill and well individuals, particularly in those from third world countries, and their role if any, in human diarrhea remains uncertain.

The remainder of the human gastroenteritis viruses listed in Table 1 are small (20 to $40 \mathrm{~nm}$ in diameter), and generally round in shape. They form the topic of this chapter, and have often been referred to as the "small round gastroenteritis viruses." In addition to their morphological similarities, they share other characteristics in common. These agents have been extremely refractory to in vitro cultivation, and, to date, only the astroviruses have been adapted to growth in cell culture. This is in contrast to many field isolates of 
rotavirus and enteric adenovirus, which now can be cultivated in vitro, albeit inefficiently in specialized or manipulated cell lines. Furthermore, several of the small round gastroenteritis viruses are closely linked to epidemic outbreaks of acute gastroenteritis. There is also evidence, either direct or in-direct, that most of these agents possess single stranded RNA. The dif-ficulties in studying the biology of these agents have also led to their consideration in common; however, this should not imply that these viruses are necessarily related viro-

TABLE 1. Human Gastroenteritis Viruses

\begin{tabular}{|c|c|c|c|c|}
\hline Virus & $\begin{array}{l}\text { Virion } \\
\text { Diameter } \\
(\mathrm{nm})\end{array}$ & $\begin{array}{l}\text { Nucleic } \\
\text { Acid } \\
\text { Type }\end{array}$ & \multicolumn{2}{|c|}{$\begin{array}{l}\text { Medical } \\
\text { Importance } \\
\text { Demonstrated }\end{array}$} \\
\hline Rotavirus & $70-75$ & dsRNA ${ }^{a}$ & $\begin{array}{l}\text { Major pathogen of young } \\
\text { children and infants in } \\
\text { winter months; adults } \\
\text { typically asymptomatic, } \\
\text { occasionally ill. }\end{array}$ & Yes \\
\hline $\begin{array}{l}\text { Non-Group A } \\
\text { Rotavirus }\end{array}$ & $70-75$ & dsRNA & $\begin{array}{l}\text { Diarrheal outbreaks in } \\
\text { China, often in adults, } \\
\text { often waterborne. }\end{array}$ & $\begin{array}{l}\text { Only in } \\
\text { China }\end{array}$ \\
\hline $\begin{array}{l}\text { Enteric } \\
\text { Adenovirus }\end{array}$ & $70-80$ & dsDNA & $\begin{array}{l}\text { Endemic diarrhea of infants } \\
\text { and young children in temper- } \\
\text { ate climates. }\end{array}$ & Yes \\
\hline $\begin{array}{l}\text { Enteric } \\
\text { Coronavirus }\end{array}$ & $100-150$ & SSRNA & $\begin{array}{l}\text { Uncertain, (?) role in necro- } \\
\text { tizing enterocolitis of } \\
\text { infants. }\end{array}$ & No \\
\hline Norwalk virus & $27-32$ & Not known & $\begin{array}{l}\text { Epidemics in older children } \\
\text { and adults; often spread from } \\
\text { contaminated water or under- } \\
\text { cooked shellfish. }\end{array}$ & Yes \\
\hline $\begin{array}{l}\text { Norwalk-like } \\
\text { Viruses } \\
\text { (Other "SRSV")C }\end{array}$ & $27-40$ & Not known & $\begin{array}{l}\text { Probably similar to Nor- } \\
\text { walk, with Snow Mountain, } \\
\text { Hawaii as examples. }\end{array}$ & ?artially \\
\hline Calicivirus & $27-38$ & SSRNA & $\begin{array}{l}\text { Usually young children; } \\
\text { shellfish-borne spread } \\
\text { occurs in adults. }\end{array}$ & Partially \\
\hline Astrovirus & $27-32$ & SSRNA & $\begin{array}{l}\text { Some outbreaks described } \\
\text { in young children. }\end{array}$ & artially \\
\hline $\begin{array}{l}\text { Small Round } \\
\text { Featureless } \\
\text { Agents }\end{array}$ & $20-26$ & Not known & $\begin{array}{l}\text { Weak evidence for disease, } \\
\text { with serological proof of } \\
\text { recent infection lacking } \\
\text { (e.g. W, Ditchling, cockle } \\
\text { agents). }\end{array}$ & No \\
\hline
\end{tabular}

a $d s=$ double-stranded

b ss = single stranded

c SRSV $=$ Small round structured viruses 
logically and, indeed, it is already known for example, that the astroviruses and caliciviruses are quite distinct from one another.

\section{COMPARATIVE MEDICAL VIROLOGY OF SMALL ROUND GASTROENTERITIS VIRUSES}

The first of these viruses to be studied was Norwalk virus (Blacklow et al. 1972; Kapikian et al. 1972); it can be considered the prototype agent also because more is known about its medical virology than the other small round gastroenteritis viruses. In a careful series of comparative EM studies, Caul has attempted to categorize all of the small viruses morphologically and his efforts provide a useful basis for discussing these agents (Caul and Appleton, 1982; Caul, 1988). Norwalk virus and similar agents form a first category, as shown in Table 2, namely, small round structured viruses (SRSV's) or Norwalk-like viruses as they have also been called (Christensen, 1989). These agents all share an amorphous surface structure with a feathery ragged outline that lacks geometric symmetry. They also share characteristics of density in cesium chloride (range 1.34-1.42 $\mathrm{gm} / \mathrm{cm}^{3}$ ) and their derivations from epidemics or family outbreaks of gastroenteritis. Indeed, for the most part they have been named after the location of the outbreak (eg, Norwalk, Ohio; Hawaii; Snow Mountain, Colorado; Montgomery County, Maryland; Taunton, England; Otofuke and Sapporo, Japan). As shown in Table 2, at least three of these viruses are distinct, based on immune electron microscopy (IEM) studies of their immunological relatedness. These three agents, Norwalk, Hawaii, and Snow Mountain, have also induced disease in human volunteers (Dolin et al. 1971, 1982; Schreiber et al. 1974), thereby providing the necessary human clinical materials for development of immunoassays to detect each of these viruses in stools and their antibodies in sera (Blacklow et al. 1979; Dolin et al. 1986; Greenberg et al. 1978; Treanor et al. 1988b). Little clinical and immunological information is available about the other small round structured viruses listed in Table 2, as they have not been administered to volunteers or had immunoassays developed.

The second category of viruses outlined in Table 2 is encompassed by the caliciviruses and the astroviruses. These viruses have a definitive classical surface structure as visualized by EM. The virion surface of caliciviruses has cupshaped indentations or hollows (Latin calix: cup) which may form a six pointed star ("Star of David"). The astroviruses, by contrast, have a five or six-pointed star appearing on their surface which consists of a continuous unbroken rounded structure unlike the caliciviruses for which the surface structure is broken by the hollows. These morphologic features of the caliciviruses and astroviruses are described thoroughly elsewhere (Madeley, 1979b). Immunoassays have recently been developed for the detection of caliciviruses and astroviruses (Herrmann et al. J. Infect. Dis., In Press; Nakata et al. 1988) and will provide the means to assess fully their medical importance as human pathogens, in the same way that immunoassay permitted the recognition of the medical importance of Norwalk virus. It is already known that, despite their morphologic differences, Norwalk virus and two strains of human calicivirus share some immunologic relatedness based on human immune responses to Norwalk virus developing in patients with calicivirus gastroenteritis (Cubitt et al. 1987).

The third category of small round viruses said to be associated with gastroenteritis is comprised of certain small round featureless viral particles (Table 2). Their structure lacks discernible surface features and a sharply delineated outer 
TABLE 2. Clinical and Immunological Relationships Among Small Round Gastroenteritis Viruses

\begin{tabular}{|c|c|c|c|c|}
\hline Virus & Category & $\begin{array}{l}\text { uction of Diseas } \\
\text { in Adult } \\
\text { Volunteers }\end{array}$ & $\begin{array}{l}\text { se } \\
\text { Immunoassay } \\
\text { Developed }\end{array}$ & $\begin{array}{l}\text { Immunological } \\
\text { Relationships } \\
\text { Studied }\end{array}$ \\
\hline Norwalk & $\begin{array}{l}\text { SRSVa } \\
\text { (Norwalk-like) }\end{array}$ & Yes & Yes & $\begin{array}{l}\text { Distinct from } \\
\text { Hawaii, Snow } \\
\text { Mountain; related } \\
\text { to Montgomery } \\
\text { County, calici- } \\
\text { virus }\end{array}$ \\
\hline Hawaii & $\begin{array}{l}\text { SRSV } \\
\text { (Norwalk-like) }\end{array}$ & Yes & Yes & $\begin{array}{l}\text { Distinct from } \\
\text { Norwalk, Snow } \\
\text { Mountain, Mont- } \\
\text { gomery County }\end{array}$ \\
\hline $\begin{array}{l}\text { Snow } \\
\text { Mountain }\end{array}$ & $\begin{array}{l}\text { SRSV } \\
\text { (Norwalk-like) }\end{array}$ & Yes & Yes & $\begin{array}{l}\text { Distinct from } \\
\text { Norwalk, Hawaii, } \\
\text { Montgomery County }\end{array}$ \\
\hline $\begin{array}{l}\text { Montgomery } \\
\text { County }\end{array}$ & $\begin{array}{l}\text { SRSV } \\
\text { (Norwalk-like) }\end{array}$ & Yes & No & $\begin{array}{l}\text { Related to Nor- } \\
\text { walk (identical?) }\end{array}$ \\
\hline $\begin{array}{l}\text { Taunton } \\
\text { (UK) }\end{array}$ & $\begin{array}{l}\text { SRSV } \\
\text { (Norwalk-like) }\end{array}$ & Not Done & No & $\begin{array}{l}\text { Distinct from } \\
\text { Astrovirus }\end{array}$ \\
\hline $\begin{array}{l}\text { Other } \\
\text { "SRSV's" }\end{array}$ & $\begin{array}{l}\text { SRSV } \\
\text { (Norwalk-like) }\end{array}$ & Not Done & No & No \\
\hline $\begin{array}{l}\text { Otofuke } \\
\text { and } \\
\text { Sapporo }\end{array}$ & $\begin{array}{l}\text { SRSV } \\
\text { (Norwalk-like) }\end{array}$ & Not Done & No & $\begin{array}{l}\text { Otofuke and Sap- } \\
\text { poro are related, } \\
\text { but not related } \\
\text { to Norwalk }\end{array}$ \\
\hline $\begin{array}{l}\text { Calici- } \\
\text { virus }\end{array}$ & $\begin{array}{l}\text { Classically } \\
\text { structured }\end{array}$ & Not Done & Yes & $\begin{array}{l}\text { Related to Nor- } \\
\text { walk. Distinct } \\
\text { from Astrovirus }\end{array}$ \\
\hline Astrovirus & $\begin{array}{l}\text { Classically } \\
\text { structured }\end{array}$ & $\begin{array}{l}\text { Infection in- } \\
\text { duced but not } \\
\text { disease }\end{array}$ & Yes & $\begin{array}{l}\text { Distinct from } \\
\text { Norwalk, Hawaii, } \\
\text { Snow Mountain, } \\
\text { calicivirus }\end{array}$ \\
\hline $\begin{array}{l}\text { Marin } \\
\text { County }\end{array}$ & $\begin{array}{l}\text { Classically } \\
\text { structured }\end{array}$ & $\begin{array}{l}\text { Infection in- } \\
\text { duced but not } \\
\text { disease }\end{array}$ & Yes & $\begin{array}{l}\text { Is Astrovirus } \\
\text { Type } 5\end{array}$ \\
\hline $\begin{array}{l}\text { W, Ditch- } \\
\text { ling, } \\
\text { cockle, } \\
\text { Paramatta }\end{array}$ & $\begin{array}{l}\text { Small round } \\
\text { featureless } \\
\text { (parvoviruses?) }\end{array}$ & Not Done & No & $\begin{array}{l}\text { Distinct from } \\
\text { Norwalk }\end{array}$ \\
\hline
\end{tabular}

a SRSV: Small round structured viruses. 
edge, in contrast to the SRSV's which do possess a delineated outline, albeit feathery and ragged. Also, the small round featureless particles seem to be smaller than 27-40nm sized SRSV's, caliciviruses and astroviruses (Tables 1 and 2), being reported as $20-26 \mathrm{~nm}$ in diameter (Caul, 1988). These smaller agents include Ditchling, W (Wollan), cockle and Paramatta (Caul, 1988), all of which have been seen in stools of individuals experiencing epidemic gastroenteritis. However, the etiological relationship of these small agents to gastroenteritis is not clear, because serological evidence of recent infection with most of these agents is lacking, unlike the case for the SRSV's, astroviruses and caliciviruses. It has been suggested that these $20-26 \mathrm{~nm}$ particles represent parvoviruses in feces that are passengers and bear no clear relationship to gastroenteritis (Caul, 1988).

With this background information about the comparative medical virology of small round gastroenteritis viruses in mind, Norwalk virus, other SRSV's, caliciviruses and astroviruses will now be discussed individually. The smaller 20-26nm Ditchling, W, cockle and Paramatta agents will not be covered due to their lack of clear association with gastroenteritis (see above).

\section{NORWALK VIRUS}

Norwalk virus was the first viral agent to be definitively associated etiologically with human gastroenteritis (Blacklow et al. 1972; Kapikian et al. 1972). It was first captured for laboratory study by human volunteer experiments (Dolin et al. 1971), and then detected by IEM in the stools of these volunteers (Kapikian et al. 1972). Because of an extensive series of human experimental studies performed with Norwalk virus during the 1970's, clinical material (stools and paired sera) became available for the development of immunoassays to recognize the virus in stools and its antibodies in human sera (Blacklow et al. 1979; Greenberg et al. 1978). These immunoassays have been the prerequisite for our understanding of the medical importance of Norwalk virus as a major cause of epidemics of gastroenteritis (Greenberg et al. 1979b, Kaplan et al. 1982). It is interesting that, despite our understanding of Norwalk virus epidemiology, this virus has still to be cultivated in cell culture, despite intensive efforts. Moreover, none of the Norwalk-like viruses (SRSV's) have been cultivated to date, and far fewer human volunteer studies have been performed with the Norwalk-like agents than with Norwalk virus. As a result, there are limited defined human clinical materials with which to set up immunoassays for the SRSV's and to perform widespread epidemiological investigations to ascertain their medical importance. Thus, little is known about the medical importance of the SRSV's in contrast to Norwalk virus, and, in order to discuss these agents, we of necessity must concentrate on the prototype agent, Norwalk virus.

\section{Biological Characteristics}

As viewed by IEM, Norwalk virus is a round-shaped, non-enveloped particle, $27 \mathrm{~nm}$ in its average diameter, with a feathery, ragged outline that is difficult to recognize in feces by direct EM (Kapikian et al. 1972). This is probably because the virus is shed in relatively low titer in feces (in contrast to rotavirus, for example) and is also small.By IEM reaction with human convalescent sera possessing Norwalk antibodies, particles are aggregated and are then able to be visualized. No clearcut substructure is apparent, perhaps due to its being ob- 
scured by antibody in the IEM reaction; however, a suggestion of small indentations on the virion surface has been described, although these are not as pronounced as the cupshaped depressions of caliciviruses (Kapikian and Chanock, 1985). Also, most IEM studies of Norwalk virus have been performed on $70^{\circ} \mathrm{C}$ stored stool specimens, which has been reported to obscure charac-teristic calicivirus morphology seen in fresh stool samples (Cubitt et al. 1987). It has not been possible to visualize Norwalk virus particles in EM studies of small intestinal mucosa biopsy specimens from infected volunteers.

Because Norwalk virus has not been cultivated in cell culture and is also shed in relatively small amounts in feces, the nature of its nucleic acid has not been determined. However, sufficient amounts of virus have been purified from feces to determine its protein composition. The virion possesses a single structural protein of molecular weight 59,000 daltons (Greenberg et al. 1981a). The only defined group of animal viruses known to possess one major virion structural protein of reported similar molecular weight is the calicivirus group. Although Norwalk virus lacks the characteristic calicivirus cup-shaped depressions on the surface of the virion, it has shown hints of surface indentations and has mostly been examined in stool samples that have been frozen and thawed, as mentioned above.

\section{Clinicopathological Findings}

The name, Norwalk virus, is derived from an outbreak of "winter vomiting disease" that occurred in the community of Norwalk, Ohio in 1968 (Dolin et al. 1971). A bacteria- and toxin-free filtrate derived from the stool of an affected adult in the outbreak reproduced the naturally occurring disease syndrome when administered orally to healthy adult volunteers (Dolin et al. 1971). Subsequent volunteer studies helped to delineate the clinical findings and pathophysiology of Norwalk virus infection. Approximately half of inoculated volunteers developed illness, with a spectrum of symptoms ranging from diarrhea without vomiting in some, to vomiting without diarrhea in others, and to both diarrhea and vomiting in additional individuals. Thus, it seems that the descriptive syndromes of "winter vomiting disease" and "viral diarrhea" may be produced by the same agent. Illness develops following an 18 to 48 hour incubation period and is self-limited, generally lasting for 12 to 48 hours.

Norwalk virus gastroenteritis is accompanied by a mucosal lesion of the proximal small intestine that is characterized by damage to villous absorptive cells, infiltration of the lamina propria by polymorphonuclear leukocytes and mononuclear cells, and villous shortening with crypt hypertrophy (Schreiber et al. 1973). These changes are associated with malabsorption of d-xylose, lactose and fat, and revert to normal within two weeks of the onset of illness. By contrast, there is no alteration of the morphology of the rectal or gastric mucosa during illness, fecal leukocytes are not present, and gastric secretion of hydrochloric acid, pepsin, and intrinsic factor are not altered. Thus, the term "enteritis" may seem appropriate for this clinical entity. However, there is a marked delay in gastric emptying, and this abnormal gastric motor function is likely responsible for the nausea and vomiting that often occurs with Norwalk illness (Meeroff et al. 1980). Based on this observation, it is proper to categorize this clinical entity as "gastroenteritis." Oral administration of bismuth subsalicylate reduced the severity and duration of abdominal cramps in ill volunteers and shortened gastrointestinal symptoms from 20 to 14 hours (Steinhoff et al. 1980). 


\section{Diagnosis}

Norwalk virus can be detected in stools by IEM (Kapikian et al. 1972), and a general rating of serum antibody activity can be made by its ability to clump the virus in an IEM reaction (Parrino et al. 1977). However, the IEM technique is obviously cumbersome and not suited for routine or rapid diagnosis. Norwalk viral antigen was first detected in stools by radioimmunoassay (RIA) and serum antibody to the virus measured by an RIA blocking test (Blacklow et al. 1979; Greenberg et al. 1978). These RIA tests, and all subsequent immunoassays that have been developed rely upon the use of stools and sera from human volunteers as critical reagents. As a result, all diagnostic assays for Norwalk virus and its antibodies are restricted to the few research laboratories that possess the necessary human reagents. There are no commercially available assays for Norwalk virus. The virus has not been able to be purified sufficiently from human stool to permit preparation of the hyperimmune animal serum reagents needed for diagnostic purposes.

An enzyme-linked immunosorbent assay (ELISA) to detect Norwalk virus antigen in stools has been developed that is more sensitive than the RIA test (Herrmann et al. 1985, 1986). It is also more convenient than RIA as it does not require radioactivity and expensive laboratory equipment; instead it uses horseradish peroxidase as its label. A biotin-avidin ELISA test has also been developed that measures both Norwalk antigen and antibody (Gary et al. 1985). IgM antibody responses to Norwalk virus can be detected and indicate recent infection, but the IgM assays also require reagents derived from human volunteers (Cukor et al. 1982; Erdman et al. 1989).

\section{Epidemiology}

The epidemiology of Norwalk virus as a medically important pathogen has been well defined using the immunoassays described above. Disease usually occurs in an epidemic fashion. Forty-two percent of 74 acute gastroenteritis outbreaks studied in the United States were associated with Norwalk virus, and an additional $23 \%$ were provisionally associated (a minority of patients with seroconversions) with the virus or related viruses (Kaplan et al. 1982). These outbreaks typically occur in certain settings: recreational camps, cruise ships, contaminated drinking or swimming water, ingestion of raw or poorly cooked shellfish, nursing homes, schools (elementary to college), and community or family locations. Outbreaks occur during all seasons, affecting older children and adults, but sparing infants and young children. Antibody prevalence levels by age in the United States are very low in childhood, and rapidly rise during adolescence and early adulthood, reaching about $60 \%$ of the population by middle age. In developing tropical nations such as Thailand, Bangladesh, Ecuador and the Philippines, antibody prevalence levels rise at the earlier ages of 2 to 6 years (Cukor et al. 1980; Greenberg et al. 1979a). Infection has been conclusively shown to be spread by the fecal-oral route based on volunteer experiments (Blacklow et al. 1972; Dolin et al. 1971). There are some epidemiological data to suggest air-borne transmission of a Norwalk-like virus hospital outbreak in which it was hypothesized that the virus became airborne as a result of explosive diarrhea and vomiting or by movement of contaminated laundry (Sawyer et al. 1988). This hypothesis is consistent with the reported detection of Norwalk virus in vomitus (Greenberg et al. 1979c). It also fits logically with the extremely rapid secondary spread of Norwalk virus infection that is often observed. 


\section{Clinical Immunity}

Our understanding of the clinical immunity to Norwalk virus infection is derived primarily from human volunteer studies. When a group of 12 volunteers was inoculated with Norwalk virus and rechallenged 27 to 42 months later, the same six volunteers who became ill on the first challenge again became ill on rechallenge (Parrino et al. 1977). Significant serum antibody rises, usually from baselines of pre-existing antibody, occurred with each illness. The six volunteers who were clinically well on the initial challenge remained well on rechallenge. Moreover, serological responses and prechallenge Norwalk antibody were for the most part absent in these non-ill volunteers. Short-term resistance to illness was observed as most previously ill volunteers remained well when rechallenged 4 to 14 weeks later (Blacklow et al. 1972, 1979; Parrino et al. 1977).

These studies indicate that the rise in serum antibody seen after Norwalk illness appears to be a marker for infection in susceptible individuals but lacks a protective role. Also, Norwalk illness commonly occurs in the presence of serum antibody. In contrast, those who resist illness usually have low or absent levels of antibody both prior to and after exposure to the virus. Intestinal antibody levels follow the same pattern as serum antibody (Blacklow et al. 1979; Greenberg et al. 1981b). The explanation for this pattern of clinical immunity is unclear. One unproven suggestion relies on a genetic control of Norwalk virus resistance or susceptibility, perhaps at the level of intestinal receptor sites. Another possible explanation is that repetitive exposures to the virus are needed to generate eventual illness and immune response. This would indicate that the resistant volunteers have had fewer naturally occurring previous exposures to the virus than susceptible subjects. Regardless, it is quite clear that immunity to Norwalk virus is not long lasting and that repeated bouts of illness throughout life would seem possible. This is consistent with the frequent role of Norwalk virus in nursing home outbreaks of gastroenteritis.

\section{Immunological Relatedness To Caliciviruses}

Human immune responses to Norwalk virus detected by RIA have developed in patients experiencing gastroenteritis caused by two well-defined strains of human caliciviruses (Cubitt et al. 1987). Human caliciviruses can be divided into several serologically distinct strains, using IEM (Cubitt et al. 1987). In two gastroenteritis outbreaks, due to the UK4 strain of calicivirus, 16 of 20 (80\%) symptomatic patients developed seroconversions by IEM to the etiologic agent UK4. Twelve of these $20(60 \%)$ patients also developed antibody rises by immunoassay to Norwalk virus. In another two gastroenteritis outbreaks due to the UK2 strain of calicivirus, 8 of $8(100 \%)$ symptomatic patients developed seroconversions by IEM to the etiologic agent, UK2. Two of these $8(25 \%)$ patients also developed antibody rises by RIA to Norwalk virus. These data, relying upon naturally occurring human immune responses, support the concept that Norwalk virus belongs to the family Caliciviridae which is also suggested by the morphological and biochemical characteristics of the virus outlined above in the section on "Biological Characteristics".

\section{NORWALK-LIKE VIRUSES}

The Norwalk-like viruses (SRSV's) share with Norwalk virus the morphological and biophysical characteristics described in the "Comparative Virol- 
ogy" section above. They are also derived from epidemic or family outbreaks of gastroenteritis and are listed in Table 2. Much less information is available for each of these agents than for Norwalk virus. They are discussed individually, below.

\section{Hawaii}

The Hawaii agent was first described in a family diarrheal outbreak and is an antigenically distinct agent from Norwalk virus and the Montgomery County agent based on cross challenge studies in volunteers (Wyatt et al. 1974). It produces clinically indistinguishable disease from Norwalk virus, and also induces a similar reversible proximal small intestinal lesion (Schreiber et al. 1974). The virus particle is able to be visualized in feces by IEM, and is immunologically distinct by IEM testing from Norwalk, Montgomery County and Snow Mountain agents (Dolin et al. 1982; Thornhill et al. 1977). As is the case for all of the Norwalk-like viruses, limited human clinical materials are available for the establishment of immunoassays for widespread use which would permit an understanding of Hawaii's epidemiological and biological properties. Recently, an ELISA test that has detected Hawaii antigen in stools of volunteers and seroconversion in these subjects has been described (Treanor et al. 1988b). The ELISA antigen test has also confirmed the antigenic distinctiveness of Hawaii from the Norwalk and Snow Mountain agents.

\section{Snow Mountain}

The Snow Mountain agent (SMA) is derived from a gastroenteritis outbreak at a resort camp in Colorado and was first identified in stools of volunteers by IEM (Dolin et al. 1982). Like Norwalk virus, it possesses a single structural protein of molecular weight 62,000 , which is compatible with the calicivirus group (Madore et al. 1986a). Both RIA and ELISA tests have been developed to detect SMA in stools and seroconversions to the virus (Dolin et al. 1986; Madore et al. 1986b). Widespread epidemiological studies have not been performed. SMA is antigenically distinct from Hawaii and Montgomery County agents by IEM and immunoassay testing. It is interesting, however, that 2 of 21 patients in a SMA outbreak also seroconverted to Norwalk virus by RIA testing, suggesting that some antigenic determinant(s) are shared between these viruses (Guest et al. 1987).

Of particular interest has been the recent production of a monoclonal antibody against the Snow Mountain agent by in vitro immunization of murine spleen cells (Treanor et al. 1988a), a technique which has also been used to prepare monoclonal antibodies to cell cultivated astrovirus (Herrmann et al. 1988). This technique permits the use of small quantities of antigen for immunization, an important issue in attempting to raise antibodies to the currently noncultivatable Norwalk-like viruses. A monoclonal antibody of the IgM class has been prepared that reacts with purified SMA and its single structural protein but not with Norwalk or Hawaii viruses. The antibody is less efficient than standard polyclonal antibody in detecting SMA in stools by immunoassay. However, this antibody should facilitate further purification and characterization of SMA. Preparation of additional monoclonal antibodies to Norwalk-like viruses should greatly facilitate future extensive diagnostic and seroepidemiologic studies. 


\section{Montgomery County}

Derived from a family gastroenteritis outbreak in Maryland, the Montgomery County agent has produced illness in volunteers, and appears similar to Norwalk virus based on cross challenge studies in volunteers (Wyatt et al. 1974). It also seems to be identical to Norwalk virus based on IEM tests (Thornhill et al. 1977) and is now considered to be Norwalk virus.

\section{Taunton}

This agent is derived from a hospital gastroenteritis outbreak in the United Kingdom (Caul et al. 1979; Lewis et al. 1988). Its relationship to other SRSV's has not been reported. By IEM testing, an outbreak has been recently uncovered at a nursing home in Florida (Glass et al. 1989).

\section{Other SRSV's}

A few other agents have been described by EM or IEM and derived from outbreaks of gastroenteritis (Appleton, 1987; Caul and Appleton, 1982). Little is known about these agents such as whether they actually may be Norwalk virus, SMA or Hawaii agent.

\section{Otofuke and Sapporo}

The Otofuke and Sapporo agents from Japan are related to one another by IEM, but not to Norwalk virus (Kogasaka et al. 1981). The Japanese agents are reported to be 33 to $40 \mathrm{~nm}$ in diameter, in contrast to the $27 \mathrm{~nm}$ diameter reported as characteristic for Norwalk, Hawaii, Montgomery County, and Snow Mountain viruses. However, precise measurements of these agents are difficult and may vary from one laboratory to another (Caul and Appleton, 1982). For example, the Norwalk and Hawaii viruses have been estimated at 30 to $35 \mathrm{~nm}$ diameter by British workers, and, indeed, Norwalk virus has been measured by its discoverers to be 32nm in its longest diameter (Caul, 1988; Kapikian and Chanock, 1985).

\section{CALICIVIRUS}

Human calicivirus is a classically structured small round gastroenteritis virus (Table 2). Other caliciviruses are found in animals such as swine, cats, sea lions, cattle, pigs, chicken and dogs, but gastroenteritis is not a prominent feature of some of these infections. However, these animal caliciviruses have been characterized virologically to a much greater extent than the human diarrheal agent which has yet to be cultivated in vitro, and this information has been useful as a model for studying human calicivirus (Cubitt, 1987; Schaffer, 1979). The animal caliciviruses contain positive single stranded RNA and were formerly classified as a genus of the family, Picornaviridae. However, with the recognition of their distinct morphology, single major polypeptide composition, and differing genome strategy, they have been reclassified as a separate family, Caliciviridae.

Human calicivirus is detected in diarrheal stools by direct EM, and does not require IEM for its recognition. Its characteristic morphology (see 
"Comparative Medical Virology" section above) by EM has sufficed for use as a diagnostic tool. Development of more convenient assays has been slow and human volunteer studies have not been performed. An RIA to detect human calicivirus in stools has been developed using a Japanese strain, and relies upon a hyperimmune guinea pig serum raised against the virus purified from stool (Nakata et al. 1983). The assay has also been adapted to measure serum antibody (Nakata et al. 1985a). More recently, the RIA has been converted to an ELISA format to detect the virus and its antibody (Nakata et al. 1988).

At least three serologically distinct strains can be demonstrated by IEM, (UK1, UK2 and Japan) and evidence exists for two additional strains, UK3 and UK4 (Cubitt et al. 1987). The RIA for calicivirus antigen detects UK1, UK2, UK4 and Japan in stools, indicating a group-specific antigen for these viruses; however, the RIA antibody test has not detected seroconversions in patients with the two UK strains that have been studied. As mentioned above under "Norwalk virus," some patients in calicivirus UK2 and UK4 outbreaks have seroconverted to Norwalk virus, which supports the concept that Norwalk virus belongs to the family, Caliciviridae. The Norwalk virus and calicivirus strains described above are antigenically distinct, however, as they do not crossreact by IEM.

Antibody age prevalence studies indicate the acquisition of antibody during early childhood in a manner similar to that for Group A rotavirus but dif-. ferent from Norwalk virus (Cubitt and McSwiggan, 1987; Nakata et al. 1985a, 1988). By school age, most young children possess serum antibodies.

Calicivirus disease has been reported in two main epidemiological patterns (Cubitt, 1987). The primary and most frequent pattern is that of gastroenteritis in infants and young children (Cubitt and McSwiggan, 1981; Suzuki et al. 1979), which occurs in the general pediatric population as well as in schools, orphanages and in nosocomial settings. Symptoms are described as indistinguishable from rotavirus (Cubitt and McSwiggan, 1981). Three percent of children with diarrhea in day care centers in the U.S. have been reported to have their illness due to calicivirus (Matson et al. 1989), an incidence rate half that noted for rotavirus and higher than that noted for Campylobacter, Shigella, and Salmonella. One EM study of pediatric viral gastroenteritis in Buffalo, New York has found calicivirus in $2 \%$ of 304 cases in contrast to rotavirus (76\%), adenovirus (10\%), and astrovirus and other small round viruses (7\%) (Riepenhoff-Talty et al. 1983). Another pediatric EM study in London showed calicivirus in $5 \%$, rotavirus in $71 \%$, adenovirus in $14 \%$, astrovirus in $7 \%$, and Norwalk-like agents in 3\% (Cubitt, 1987). Data collected by Cubitt suggest that the UK1 and Japan strains of human calicivirus are particularly associated with pediatric gastroenteritis.

The second epidemiological pattern for calicivirus illness is indistinguishable from Norwalk virus disease. Attack rates are high in adults, and outbreaks are often associated with consumption of contaminated shellfish, water, and cold foods (Cubitt et al. 1981, 1987). This form of illness has been associated with the UK3 and UK4 strains (Cubitt, 1987), and it is particularly interesting that individuals experiencing UK4 disease have been those who have also seroconverted to Norwalk virus.

Little is known about the immune response to calicivirus. One study indicates that the presence of serum antibody to the Japan strain in infants correlates with resistance to illness (Nakata et al. 1985b). There are no comparable data reported for the UK4 strain which is the virus known to bear some similarities to Norwalk virus. 


\section{ASTROVIRUS}

Human astrovirus, like calicivirus, can be categorized as a classically structured round gastroenteritis virus (Table 2). Other astroviruses are found that produce diarrhea in animals such as sheep, cattle, cats, dogs, pigs, turkeys and ducks. These animal agents are unrelated immunologically to the human astrovirus. The human astrovirus, unlike calicivirus, can be cultivated in HEK or LLCMK2 cell cultures treated with trypsin (Herrmann et al. 1988; Lee and Kurtz, 1981), and therefore a body of information, albeit sparse, exists about the virology of the agent. It contains positive single stranded RNA that codes for four structural proteins (Kurtz, 1989; Kurtz and Lee, 1987) of similar molecular weight as is found in picornaviruses; however, the distinctive star-shaped morphology of astrovirus distinguishes it from the picornaviruses.

Five serotypes of human astrovirus are described (Kurtz and Lee, 1984). These include the Marin County agent, which was uncovered in a gastroenteritis outbreak that occurred in a convalescent home for the elderly (Oshiro et al. 1981). The difficulties in categorizing correctly small round gastroenteritis viruses are exemplified by the Marin County agent which was originally described as a Norwalk-like virus (Oshiro et al. 1981). However the Marin County agent is now known to be an astrovirus type 5 that possesses some cross-reactivity with type 1 (Herrmann et al. 1987). Astrovirus is distinct immunologically from Norwalk virus, Hawaii virus, SMA and calicivirus (Herrmann et al. 1988; Konno et al. 1982).

Human astrovirus can be detected in diarrheal stools by direct EM, and this has served, until recently, as the only diagnostic tool for this agent. All published studies on the clinical and epidemiological features of infection have relied entirely on EM, and therefore, a complete understanding of the medical and epidemiological importance of this agent is lacking because of the cumbersome nature of EM. Recently, however, astrovirus-specific monoclonal antibodies have been prepared that react with a common group antigen shared by all astrovirus serotypes including the Marin County agent (Herrmann et al. 1988). These monoclonal antibodies have now been employed in an ELISA format to detect astroviruses in stools with a high degree of sensitivity and specificity (Herrmann et al. J. Infect. Dis., In Press). Thus, a simple and convenient means now exists to facilitate studies on the importance of astroviruses in gastroenteritis.

Antibody age prevalence studies, using IEM or immunofluorescence, indicate the acquisition of antibody in over $70 \%$ of British children by 3 to 4 years of age (Kurtz and Lee, 1978) and the presence of antibody in $50 \%$ of young adults in Japan (Konno et al. 1982). Recently, an RIA to detect IgM and IgG antibodies to astrovirus has been developed and has established that antibodies to astrovirus type 1 are present in half of British children 6 to 23 months of age (Wilson and Cubitt, 1988).

Descriptions of astrovirus clinical illness are limited in scope. Watery diarrhea is prominent and vomiting is said to be less common (Kurtz, 1989; Kurtz and Lee, 1987). Illness is most frequent in young children from infancy up to 7 years of age (Ashley et al. 1978; Konno et al. 1982; Kurtz et al. 1977), and appears to be less severe than rotavirus diarrhea (Kurtz et al. 1977). Eighty percent of 79 babies infected with astrovirus had diarrhea (Madeley, 1979a). Adult infection is usually asymptomatic or mild (Konno et al. 1982; Kurtz et al. 1977; Oshiro et al. 1981), but outbreaks in adults are described in residential facilities for the elderly (Gray et al. 1987; Oshiro et al. 1981). 
When administered to eight adult volunteers, an astrovirus containing inoculum produced disease in one subject who also shed large amounts of virus (Kurtz et al. 1979). Nine subsequent volunteers were given a fecal filtrate derived from the volunteer with diarrhea, and astrovirus shedding subsequently occurred in two of them without illness. Virus specific antibody rises were noted in 13 of 16 inoculated volunteers studied. It thus appears that the astrovirus strain studied causes a transmissible infection that is of low pathogenicity for adults. These findings are also consistent with the usual mild or asymptomatic infection pattern felt to occur in adults; however, it is also clear from the Marin County agent outbreak that illness can be prominent in adults (Oshiro et al. 1981). In regard to clinical immunity, it is clear that in the presence of serum antibody, infection of volunteers did not result in diarrhea (Kurtz et al. 1979).

\section{REFERENCES}

Appleton, H (1987) Small round viruses: classification and role in food-borne infections. In Novel Diarrhoea Viruses. CIBA Foundation Symposium 128, Chichester: John Wiley and Sons, pp. 108-119.

Ashley CR, Caul EO, Paver WK (1978) Astrovirus-associated gastroenteritis in children. J Clin Pathol 31:939-943.

Blacklow NR, Dolin R, Fedson DS, DuPont H, Northrop RS, Hornick RB, Chanock RM (1972) Acute infectious nonbacterial gastroenteritis: etiology and pathogenesis. Ann Intern Med 76:993-1008.

Blacklow NR, Cukor G, Bedigian MK, Echeverria P, Greenberg HB, Schreiber DS, Trier JS (1979) Immune response and prevalence of antibody to Norwalk enteritis virus as determined by radioimmunoassay. J Clin Microbiol 10:903-909.

Caul EO (1988) Small round human fecal viruses. In Pattison JR (ed), Parvoviruses and Human Disease. Boca Raton: CRC Press, pp. 139-163.

Caul EO, Appleton H (1982) The electron microscopical and physical characteristics of small round human fecal viruses: an interim scheme for classification. J Med Virol 9:257-265.

Caul EO, Ashley CR, Pether JVS (1979) "Norwalk-like" particles in epidemic gastroenteritis in the UK. Lancet 2:1292.

Christensen ML (1989) Human viral gastroenteritis. Clin Microbiol Rev 2:5189.

Cubitt WD (1987) The candidate caliciviruses. In Novel Diarrhoea Viruses. CIBA Foundation Symposium 128. Chichester: John Wiley and Sons, pp. 157-179.

Cubitt WD, McSwiggan DA (1981) Calicivirus gastroenteritis in North West London. Lancet 2:975-977.

Cubitt WD, McSwiggan DA (1987) Seroepidemiological survey of the prevalence of antibodies to a strain of human calicivirus. J Med Virol 21:361368.

Cubitt WD, Pead PJ, Saeed AA (1981) A new serotype of calicivirus associated with an outbreak of gastroenteritis in a residential home for the elderly. J Clin Pathol 34:924-926.

Cubitt WD, Blacklow NR, Herrmann JE, Nowak NA, Nakata S, Chiba S (1987) Antigenic relationships between human caliciviruses and Norwalk virus. J Infect Dis 156:806-814. 
Cukor G, Blacklow NR (1984) Human viral gastroenteritis. Microbiol Rev 48:157-179.

Cukor G, Blacklow NR, Echeverria P, Bedigian MK, Puruggan H, Basaca-Sevilla V (1980) Comparative study of the acquisition of antibody to Norwalk virus in pediatric populations. Infect Immun 29:822-823.

Cukor G, Nowak NA, Blacklow NR (1982) Immunoglobulin M responses to the Norwalk virus of gastroenteritis. Infect Immun 37:463-468.

Dolin R, Blacklow NR, DuPont H, Formal S, Buscho RF, Kasel JA, Chames RP, Hornick R, Chanock RM (1971) Transmission of acute infectious nonbacterial gastroenteritis to volunteers by oral administration of stool filtrates. J Infect Dis 123:307-312.

Dolin R, Reichman RC, Roessner KD, Tralka TS, Schooley RT, Gary W, Morens D (1982) Detection by immune electron microscopy of the Snow Mountain agent of acute viral gastroenteritis. J Infect Dis 146:184- 189.

Dolin R, Roessner KD, Treanor JJ, Reichman RC, Phillips M, Madore HP (1986) Radioimmunoassay for detection of the Snow Mountain agent of viral gastroenteritis. J Med Virol 19:11-18.

Erdman DD, Gary GW, Anderson LJ (1989) Development and evaluation of an IgM capture enzyme immunoassay for diagnosis of recent Norwalk virus infection. J Virol Meth 24:57-66.

Gary GW Jr, Kaplan JE, Stine SE, Anderson LJ (1985) Detection of Norwalk virus antibodies and antigen with a biotin-avidin immunoassay. J Clin Microbiol 22:274-278.

Glass RI, Monroe SS, Stine S, Madore P, Lewis D, Cubitt D, Grohmann G, Ashley C (1989) Small round structured viruses: the Norwalk family of agents. In Farthing, MJG (ed.), Viruses and the Gut. London: Swan Press Ltd., pp. 87-90.

Gray JJ, Wreghitt TG, Cubitt WD, Elliot PR (1987) An outbreak of gastroenteritis in a home for the elderly associated with astrovirus type 1 and human calicivirus. J Med Virol 23:377-381.

Greenberg HB, Wyatt RG, Valdesuso J, Kalica AR, London WT, Chanock RM, Kapikian AZ (1978) Solid-phase microtiter radioimmunoassay for detection of the Norwalk strain of acute nonbacterial epidemic gastroenteritis virus and its antibodies. J Med Virol 2:97-108.

Greenberg HB, Valdesuso J, Kapikian AZ, Chanock RM, Wyatt RG, Szmuness W, Larrick J, Kaplan J, Gilman RH, Sack DA (1979a) Prevalence of antibody to the Norwalk virus in various countries. Infect Immun 26:270-273.

Greenberg HB, Valdesuso J, Yolken RH, Gangarosa E, Gary W, Wyatt RG, Konno J, Suzuki H, Chanock RM, Kapikian AZ (1979b) Role of Norwalk virus in outbreaks of nonbacterial gastroenteritis. J Infect Dis 139:564-568.

Greenberg HB, Wyatt RG, Kapikian AZ (1979c) Norwalk virus in vomitus. Lancet 1:55.

Greenberg HB, Valdesuso JR, Kalica AR, Wyatt RG, McAuliffe VJ, Kapikian AZ, Chanock RM (1981a) Proteins of Norwalk virus. J Virol 37:994-999.

Greenberg HB, Wyatt RG, Kalica AR, Yolken RH, Black R, Kapikian AZ, Chanock RM (1981b) New insights in viral gastroenteritis. Perspect Virol 11:163-187.

Guest C, Spitalny KC, Madore HP, Pray K, Dolin R, Herrmann JE, Blacklow NR (1987) Foodborne Snow Mountain Agent gastroenteritis in a school cafeteria. Pediatrics 79:559-563.

Herrmann JE, Nowak NA, Blacklow NR (1985) Detection of Norwalk virus in stools by enzyme immunoassay. J Med Virol 17:127-133. 
Herrmann JE, Kent GP, Nowak NA, Brondum J, Blacklow NR (1986) Antigen detection in the diagnosis of Norwalk virus gastroenteritis. J Infect Dis 154:547-548.

Herrmann JE, Hudson RW, Blacklow NR, Cubitt WD (1987) Marin County agent, an astrovirus. Lancet 2:743.

Herrmann JE, Hudson RW, Perron-Henry DM, Kurtz JB, Blacklow NR (1988) Antigenic characterization of cell-cultivated astrovirus serotypes and development of astrovirus-specific monoclonal antibodies. J Infect Dis 158:182-185.

Kapikian AZ, Chanock RM (1985) Norwalk group of viruses. In B.N. Fields (ed.), Virology, New York: Raven Press, pp. 1495-1517.

Kapikian AZ, Wyatt RG, Dolin R, Thronhill TS, Kalica AR, Chanock RM (1972) Visualization by immune electron microscopy of a $27-\mathrm{nm}$ particle associated with acute infectious nonbacterial gastroenteritis. J Virol 10:10751081.

Kaplan JE, Goodman RA, Schonberger LB, Lippy EC, Gary GW (1982) Gastroenteritis due to Norwalk virus: an outbreak associated with a municipal water system. J Infect Dis 146:190-197.

Kogasaka R, Nakamura S, Chiba S, Sakuma Y, Terashima H, Yokoyama T, Nakao T (1981) The 33- to 39-nm virus-like particles, tentatively designated as Sapporo agent, associated with an outbreak of acute gastroenteritis. J Med Virol 8:187-193.

Konno T, Suzuki H, Ishida N, Chiba R, Mochizuki R, Tsunoda A (1982) Astrovirus-associated epidemic gastroenteritis in Japan. J Med Virol 9:11-17.

Kurtz JB (1989) Astrovirus. In Farthing MJG (ed.), Viruses and the Gut. London: Swan Press Ltd., pp. 84-87.

Kurtz J, Lee T (1978) Astrovirus gastroenteritis age distribution of antibody. Med Microbiol Immunol 166:227-230.

Kurtz JB, Lee TW (1984) Human astrovirus serotypes. Lancet 2:1405.

Kurtz JB, Lee TW (1987) Astroviruses: human and animal. In Novel Diarrhoea Viruses. CIBA Foundation Symposium 128. Chichester: John Wiley and Sons, pp. 92-101.

Kurtz JB, Lee TW, Pickering D (1977) Astrovirus associated gastroenteritis in a children's ward. J Clin Pathol 30:948-952.

Kurtz JB, Lee TW, Craig JW, Reed SE (1979) Astrovirus infection in volunteers. J Med Virol 3:221-230.

Lee TW, Kurtz JB (1981) Serial propagation of astrovirus in tissue culture with the aid of trypsin. J Gen Virol 57:421-424.

Lewis DC, Lightfoot NF, Pether JVS (1988) Solid phase immune electron microscopy with human immunoglobulin $M$ for serotyping of Norwalk-like viruses. J Clin Microbiol 26:938-942.

Madeley CR (1979a) Viruses in the stools. J Clin Pathol 32:1-10.

Madeley CR (1979b) Comparison of the features of astroviruses and caliciviruses seen in samples of feces by electron microscopy. J Infect Dis 139:519-523.

Madore HP, Treanor JJ, Dolin R (1986a) Characterization of the Snow Mountain agent of viral gastroenteritis. J Virol 58:487-492.

Madore HP, Treanor JJ, Pray KA, Dolin R (1986b) Enzyme-linked immunosorbent assays for Snow Mountain and Norwalk agents of viral gastroenteritis. J Clin Microbiol 24:456-459.

Matson DO, Estes MK, Glass RI, Bartlett AV, Penaranda M, Calomeni E, Tanaka T, Nakata S, Chiba S (1989) Human calicivirus-associated diarrhea in children attending day care centers. J Infect Dis 159:71-78. 
Meeroff JC, Schreiber DS, Trier JS, Blacklow NR (1980) Abnormal gastric motor function in viral gastroenteritis. Ann Intern Med 92:370-373.

Nakata S, Chiba S, Terashima M, Sakuma Y, Kogasaka R, Nakao T (1983) Microtiter solid-phase radioimmunoassay for detection of human calicivirus in stools. J Clin Microbiol 17:198-201.

Nakata S, Chiba S, Terashima H, Nakao T (1985a) Prevalence of antibody to human calicivirus in Japan and Southeast Asia determined by radioimmunoassay. J Clin Microbiol 22:519-521.

Nakata S, Chiba S, Terashima H, Yokoyama T, Nakao T (1985b) Humoral immunity in infants with gastroenteritis caused by human calicivirus. J Infect Dis 152:274-279.

Nakata S, Estes MK, Chiba S (1988) Detection of human calicivirus antigen and antibody by enzyme-linked immunosorbent assays. J Clin Microbiol 26:2001-2005.

Oshiro LS, Haley CE, Roberto RR, Riggs JL, Croughlan M, Greenberg H, Kapikian A (1981) A 27-nm virus isolated during an outbreak of acute infectious nonbacterial gastroenteritis in a convalescent hospital: a possible new serotype. J Infect Dis 143:791-796.

Parrino TA, Schreiber DS, Trier JS, Kapikian AZ, Blacklow NR (1977) Clinical immunity in acute gastroenteritis caused by Norwalk agent. $\mathbf{N}$ Engl J Med 297:86-89.

Riepenhoff-Talty M, Saif LJ, Barrett HJ, Suzuki H, Ogra PL (1983) Potential spectrum of etiological agents of viral enteritis in hospitalized infants. J Clin Microbiol 17:352-356.

Sawyer LA, Murphy JJ, Kaplan JE, Pinsky PF, Chacon D, Walmsley S, Schonberger LB, Phillips A, Forward K, Goldman C, Brunton J, Fralick RA, Carter AO, Gary WG, Glass RI, Low DE (1988) 25- to 30-nm virus particle associated with a hospital outbreak of acute gastroenteritis with evidence for airborne transmission. Amer J Epid 127:1261-1271.

Schaffer FL (1979) Caliciviruses. Comp Virol 14:249-284.

Schreiber DS, Blacklow NR, Trier JS (1973) The mucosal lesion of the proximal small intestine in acute infectious non-bacterial gastroenteritis. N Engl J Med 288:1318-1323.

Schreiber DS, Blacklow NR, Trier JS (1974) The small intestinal lesion induced by Hawaii agent acute infectious nonbacterial gastroenteritis. J Infect Dis 129:705-708.

Steinhoff MC, Douglas RG Jr, Greenberg HB, Callahan DR (1980) Bismuth subsalicylate therapy of viral gastroenteritis. Gastroenterology 78:1495-1499.

Suzuki H, Konno T, Kutsuzawa T, Imai A, Tazawa F, Ishida N, Katsushima N, Sakamoto M (1979) The occurrence of calicivirus in infants with acute gastroenteritis. J Med Virol 4:321-326.

Thornhill TS, Wyatt RG, Kalica AR, Dolin R, Chanock RM, Kapikian AZ (1977) Detection by immune electron microscopy of 26 to $27 \mathrm{~nm}$ virus-like particles associated with two family outbreaks of gastroenteritis. J Infect Dis 135:20-27.

Treanor J, Dolin R, Madore HP (1988a) Production of a monoclonal antibody against the Snow Mountain agent of gastroenteritis by in vitro immunization of murine spleen cells. Proc Nat Acad Sci USA 85:3613-3617.

Treanor JJ, Madore HP, Dolin R, (1988b) Development of an enzyme immunoassay for the Hawaii agent of viral gastroenteritis. J Virol Meth 22:207-214.

Wilson SA, Cubitt WD (1988) The development and evaluation of radioimmune assays for the detection of immune globulin $M$ and $G$ against astrovirus. J Virol Meth 19:151-160. 
Wyatt RG, Dolin R, Blacklow NR, DuPont H, Buscho R, Thornhill TS, Kapikian AZ, Chanock RM (1974) Comparison of three agents of acute infectious nonbacterial gastroenteritis by cross-challenge in volunteers. J Infect Dis 129:709-714.

\section{DISCUSSION}

Wright J (Gull Laboratories, Salt Lake City, UT):

Any estimates on the size of the genome of either the astroviruses or caliciviruses?

\section{Blacklow N:}

What has been reported on this has been very minimal. John Kurtz at Oxford has preliminary data that human retrovirus has a positive-strand RNA genome of about 7,500 nucleotides. I am not aware of any data on human calcicivirus.

\section{Bishop R (Royal Children's Hospital, Melbourne, Australia):}

I was very interested that you have developed an ELISA as a monoclonal. In the past, one of the problems with identifying astros was being sure of the actual appearance. The star-shape looks lovely when you see it, but you don't always see it. I'm just wondering, you had a very good correlation between EM and an ELISA. Would you, in every case that you saw them in EM, have picked them as an astro if you hadn't had the ELISA? How often, in other words, did you see the star on those positive ones?

\section{Blacklow N:}

These samples were looked at by EM by two different laboratories, blinded. The first was by David Cubitt in London, and the second was in our laboratory by Dorothy Henry. So, the specimens were doubly confirmed as being EM positive. In our studies to date, samples have been first looked at by EM, and then by ELISA.' We have subjected other round viral particles appearing by electron microscopy to the assay, and they are negative. These include human calicivirus strains from David Cubitt, Norwalk-like specimens that we've had, Snow Mountain agent from Rochester, and others, and these have all been negative in the astrovirus monoclonal based ELISA.

\section{Riepenhoff-Talty M (Children's Hospital, Buffalo, NY):}

I wonder if you recall Maria Szymanski and Peter Middleton and their mini reo. Would you comment on what you think mini reo is?

\section{Blacklow N:}

I don't know what it represents. It definitely is not related to the Reoviridae. Most workers in the field have not detected or described mini-reovirus in stools. What has been your experience with that? 
Riepenhoff-Talty M (Children's Hospital, Buffalo, NY):

We have not been able to detect it either.

Lennette E (California Public Health Foundation, Berkeley, CA):

What about the toro viruses? You have made no reference to those, but can you say anything about the characteristics and their potential importance?

\section{Blacklow N:}

These are interesting agents which are not small round gastroenteritis viruses, they're shaped differently, being enveloped, pleomorphic and $130 \mathrm{~mm}$ in diameter. The Berne and Breda agents described by Flewett have been noted in a couple of individual cases of diarrhea. Tom Flewett in the United Kingdom has performed extensive seroepidemiologic studies for these so called toro viruses, and has not found that they seem to have any significant role at all in human diarrhea. 